\title{
Functional Analysis of the Early Chlorosis Factor Gene
}

\author{
C. Q. Morales, ${ }^{1}$ J. Posada, ${ }^{1}$ E. Macneale, ${ }^{1}$ D. Franklin, ${ }^{1}$ I. Rivas, ${ }^{1}$ M. Bravo, ${ }^{1}$ J. Minsavage, ${ }^{2}$ R. E. Stall, ${ }^{2}$ \\ and M. C. Whalen ${ }^{1}$
}

${ }^{1}$ Department of Biology, San Francisco State University, 1600 Holloway Avenue, San Francisco, CA, U.S.A.; ${ }^{2}$ Department of Plant Pathology, University of Florida, Gainesville, U.S.A.

Submitted 28 June 2004. Accepted 17 January 2005.

\begin{abstract}
Chlorosis is one of the symptoms of bacterial spot disease caused by Xanthomonas campestris pv. vesicatoria, which induces chlorosis before any other symptoms appear on tomato. We report characterization of a $2.1-\mathrm{kb}$ gene called early chlorosis factor (ecf). The gene ecf encodes a hydrophobic protein with similarity to four other proteins in plant pathogens, including HolPsyAE, and uncharacterized gene products from $X$. campestris pv. campestris and $X$. axonopodis pv. citri, and, at the tertiary structure level, to colicin Ia from Escherichia coli. We demonstrate that the associated phenotype is hrp dependent, and that the ecf gene product appears to be translocated to host cells. The gene $e c f$ has no impact on electrolyte leakage or on bacterial growth in planta in response to infection. Concentrated culture filtrates do not produce chlorosis. Study of its role in Xanthomonas spp.-tomato interactions will forward our understanding of symptom production by plant pathogens and allows further investigation into the mechanisms of bacterial virulence and production of symptoms.
\end{abstract}

Plant-pathogenic bacteria enter the plant intercellular space or apoplast through natural or wound openings. Ingress may require the expression of diffusible factors secreted by the type II system, whose activation may require an environmental signal such as sensing of a nutrient-poor environment or a specific plant factor. Once bacteria have entered the apoplast, activation of hypersensitive response and pathogenicity ( $h r p$ ) genes encoding the type III secretion system (TTSS) occurs rapidly and is triggered by contact with host cells (Brito et al. 2002) or sensing of the intercellular environment (Alfano and Collmer 1996). Early activation of the hrp system is the essential event of infection. The hrp system elaborates a proteinaceous secretion apparatus capable of delivering proteins both into the extracellular environment and across the plant cell wall and membrane (Jin et al. 2003). Proteins delivered into the extracellular environment may participate in the alkalinization of the apoplast (which occurs in part through a $\mathrm{K}+$ efflux or $\mathrm{H}+$ influx exchange response) (Alfano and Collmer 1996) and may be significant in creating or anchoring the TTSS to the plant cell wall. Numerous proteins called effectors are delivered into the plant cell via the TTSS (Buttner and Bonas 2002; Collmer at al. 2002; Cornelis

C. Q. Morales and J. Posada contributed equally to this work.

Corresponding author: M. C. Whalen; Telephone: 415-338-6475; Fax: 415-338-2295; E-mail: whalen@sfsu.edu

Current address of C. Morales: Department of Plant and Microbial Biology, University of California, Berkeley 94720, U.S.A.

Nucleotide sequence data reported are available in the GenBank database under number AY842297. and Gijsegem 2000; Greenberg and Vinatzer 2003), some of which are targeted to the nucleus (Szurek et al. 2002). These proteins are thought to suppress plant defenses or alter the plant metabolic machinery to promote nutrient synthesis or release. As a result, bacteria multiply in the intercellular space. The critical component of parasitism is the organism's ability to evade or subvert plant defense responses. The $h r p$-dependent factors are likely the key players in this process (Jin et al. 2003; Ponciano et al. 2003), and certain toxins which are also hrp dependent may suppress defense gene expression as well (Bender et al. 1999; Fouts et al. 2002; He et al. 2004; Mittal and Davis 1995). Genomic sequence data suggest that pathogenicity and virulence in plant pathogens result from the contribution of well over a hundred bacterial factors, some of which are unique to and conserved among pathogens, some of which are specific to individual pathogens, and some of which are possessed by pathogen and nonpathogen alike (Buttner et al. 2003; Buell et al. 2003; da Silva et al. 2002; Greenberg and Vinatzer 2003; PetnickiOcweija et al. 2002; Salanoubat et al. 2002; Simpson et al. 2000).

Bacterial spot disease of tomato and pepper is caused by Xanthomonas campestris pv. vesicatoria (also called X. axonopodis pv. vesicatoria and X. vesicatoria) (Jones et al. 1998) and is most prevalent in hot, humid climates (Stall 1995). In the field, the bacteria are disseminated through aerosols, enter small wounds or stomata, and produce small watersoaked lesions that become necrotic. When leaves have numerous lesions, they often coalesce and are accompanied by a general chlorosis. Chlorosis is the visible result of the loss of chlorophyll which may occur by a variety of mechanisms, including a response to the activity of toxins (Gross 1991) and ethylene (Stall and Hall 1984). This article reports the identification and physical characterization of a novel locus from $X$. campestris pv. vesicatoria that induces early chlorosis in tomato and several nonhosts. The isolation of this locus affords the opportunity to further investigate the mechanisms of bacterial virulence and production of symptoms.

\section{RESULTS}

Physical and molecular characterization

of early chlorosis factor $(e c f)$ gene.

To examine the factors that induce the response of bean to $X$. campestris pv. vesicatoria tomato races, a library of DNA from $X$. campestris pv. vesicatoria 75-3 (Minsavage et al. 1990) was screened in the bean pathogen $X$. campestris pv. phaseoli 85-6. One cosmid clone, pEC432, converted the host response from a normal watersoaking to a bright yellow chlorosis on bean cvs. Sprite and Bush Blue Lake (Tables 1 and 2). Two successive subclones, 3.4-kb pXV9038 and 2.4-kb pXV9039, yielded similar results on bean. To investigate the 
host range of the chlorotic response, pXV9038 was mobilized into X. campestris pvs. vesicatoria 89-1, glycines 202, vignicola G-55, malvacearum G-34, and campestris 8004 (Table 2), and the resulting transconjugants were inoculated into their normally susceptible hosts, tomato, soybean, cowpea, cotton, and radish, respectively. All host lines responded with a chlorotic phenotype (Table 1 ). To ascertain whether the $2.4-\mathrm{kb}$ fragment in pXV9039 contained all the sequences for full chlorosis-inducing activity on tomato, the $2.4-\mathrm{kb}$ fragment was cloned into pL6 in both orientations, creating pXV9040 and pCQM20 (Table 2). The insert gave full activity in both orientations, demonstrating that the 2.4-kb fragment was capable of conferring the chlorosis-inducing activity on $X$. campestris $\mathrm{pv}$. vesicatoria 89-1 (Fig. 1; Table 1). All fragments shorter than $2.4 \mathrm{~kb}$ were nonchlorotic (Table 2).

The timing of chlorosis in response to X. campestris pv. vesicatoria 89-1 transconjugants was studied (Fig. 2). In response to inoculation with 89-1 carrying pXV9038, pXV9039, and pXV9040, a strong chlorosis was evident beginning 1 day postinoculation (dpi) and increasing in strength up to 5 dpi. When 89-1 was inoculated, light chlorosis activity was observed beginning $3 \mathrm{dpi}$ and increasing up to $5 \mathrm{dpi}$, suggesting two distinct chlorosis activities. Therefore, we named the locus encoded in the 2.4-kb fragment ecf.

To further demonstrate that the chlorosis activity resided in these fragments, Tn5 mutagenesis was carried out. Plasmids pEC432::Tn5 and pXV9038::Tn5 lost chlorosis-inducing activity in 89-1 (Table 1). The Tn5 mutation was exchanged into the genome of $X$. campestris pv. vesicatoria 75-3 and 75-3 $a v r R x v:: \Omega$ (Whalen et al. 1988), creating 75-3 ecf::Tn5 and 75-

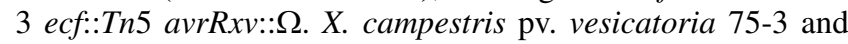
75-3 avrRxv:: $\Omega$ induced a chlorotic response on leaves of Bonny Best, whereas 75-3 ecf::Tn5 and 75-3 ecf::Tn5 avrRxv:: $\Omega$ induced watersoaking responses. The chlorosisinducing phenotype was rescued by pXV9038 but not pXV9038::Tn5 (Table 1). The timing of chlorosis induction was delayed by 2 to 3 dpi in the 75-3 ecf::Tn5 avrRxv:: $\Omega$ compared with the 75-3 avrRxv:: $\Omega$ strain (data not shown).

To investigate whether an early chlorotic phenotype correlates with the presence of ecf, genomic DNA from Xanthomo-

Table 1. Responses of susceptible hosts to strains of Xanthomonas campestris pathovars and transconjugants upon inoculation at $5 \times 10^{8} \mathrm{CFU} / \mathrm{ml}$

\begin{tabular}{|c|c|}
\hline X. campestris pathovar & Response $^{\mathbf{a}}$ \\
\hline phaseoli $85-6$ & WS \\
\hline $\mathrm{pEC} 432$ & Chl \\
\hline pXV9038 & Chl \\
\hline pXV9038::Tn5 & WS \\
\hline pXV9039 & Chl \\
\hline vesicatoria $89-1$ & WS \\
\hline pXV9038 & Chl \\
\hline pXV9038::Tn5 & WS \\
\hline pXV9039 & Chl \\
\hline pCQM20 & Chl \\
\hline glycines 202 & WS \\
\hline pXV9038 & Chl \\
\hline pXV9038::Tn5 & WS \\
\hline vignicola $\mathrm{G}-55$ & WS \\
\hline pXV9038 & Chl \\
\hline pXV9038::Tn5 & WS \\
\hline malvacearum G-34 & WS \\
\hline pXV9038 & Chl \\
\hline pXV9038::Tn5 & WS \\
\hline vesicatoria $75-3$; vesicatoria $75-3 \pm$ avrRxv:: $\Omega$ & Chl \\
\hline $\begin{array}{l}\text { vesicatoria } 75-3 \text { ecf::Tn5; vesicatoria } 75-3 \text { ecf::Tn5 } \pm \\
\text { avrRxv:: } \Omega\end{array}$ & WS \\
\hline pXV9038 & Chl \\
\hline
\end{tabular}

${ }^{a}$ Response of susceptible host to inoculation: $\mathrm{WS}=$ watersoaking and $\mathrm{Chl}=$ chlorosis. nas strains known to be chlorotic or nonchlorotic in their hosts was hybridized with probes derived from the 2.4-kb subclone. Genomic DNA from the chlorotic $X$. campestris pv. vesicatoria tomato strains 75-3 and 92-14 and pepper strains $82-8,85-$ 10, 81-23, 68-1, and 69-1 (Table 2) hybridized at the expected size in EcoRI-digested DNA (data not shown). Genomic DNA from the nonchlorotic strains $X$. campestris pv. vesicatoria 891 ; X. campestris pvs. campestris 8004, phaseoli 85-6, malvacearum, glycines, vignicola, alfalfae, holcicola, vitians, carotae, pruni, and begoniae; and the chlorotic pathovar strain campestris 2D250 (Buell and Somerville 1995) did not hybridize, suggesting that ecf is highly specific to $X$. campestris pv. vesicatoria. In $X$. campestris pv. vesicatoria strains 75-3, 82-8, 85$10,81-23,68-1$, and 69-1 ecf co-segregated with chromosomal DNA (data not shown).

\section{Sequence determination and analysis.}

The 3.6-kb clone pXV9038 was sequenced. Subclones from the inactive pXV9038::Tn5 were created and sequenced to determine that $T n 5$ was inserted at base 689 . Only one open reading frame $(\mathrm{ORF})$, in the minus orientation, produced a long ORF (ORF1) of 2,064 nucleotides encoding a theoretical 688amino acid protein with a molecular weight of approximately $74 \mathrm{kDa}$ (base 2,239 to 176) (Fig. 3A). The results from in vitro transcription and translation reactions performed on $\mathrm{p} 42$ indicated a major protein product of $74.5 \mathrm{kDa}$ and two minor products at 62 and $58 \mathrm{kDa}$ (data not shown). The two minor products were found to correspond to internal ATGs within ORF1.

The entire sequence was analyzed for Escherichia coli consensus promoter sequences and none were found. A search for a PIP-box (TTCGC-N15-TTCGC) sequence found in the promoter region of several Xanthomonas genes revealed a perfect PIP-box between bases 3,276 and 3,251 in the minus orientation (Fig. 3A). However, the fact that ecf begins over 1,000 nucleotides downstream from the PIP-box, along with the fact that a subclone without the PIP-box and without external promoters is fully active (Table 1), make it unlikely that the PIP-box is part of a promoter region specific to this ORF (Fenselau and Bonas 1995). A possible ribosome-binding site, AAGGA, is centered 10 bases upstream from the ATG start codon of ORF1 (Fig. 3A) and there is no recognizable ribosome-binding site upstream of ORF2. The inverted palindrome AGCGGCGCGGCC-N23-TCGCCGCGCCGG spans bases 1,282 through 1,328 within the ORF but has unknown significance.

The predicted amino acid sequence of the ecf gene product was analyzed using several structure prediction programs. The consensus prediction indicated that the core of ECF is highly hydrophobic and includes six potential transmembrane (TM) domains (Fig. 3B). Furthermore, the tertiary structure prediction program 3D-PSSM predicted limited but significant structural similarity to domains of colicin Ia, a pore-forming TM protein present in E. coli (Weiner et al. 1997). The similarity includes the TonB binding box in the translocation domain (Fig. 3B) and two of the highly conserved TM sequences, C8 and $\mathrm{C}$, in the channel-forming domain (Fig. 3B and C).

Various databases were searched for similarities at both the nucleotide and amino acid levels. Comparing the ecf sequence within the 3.4-kb subclone at the nucleotide level, two sets of similarities were found. The first set had significant similarity to ecf bases 2,797 to 3,195 and comprised xanthomonad insertion elements, including a few from $X$. oryzae pv. oryzae, an IS4 family member (gi:23428392), IS1113 (gi32453974), and IS1114 (gi:7453619) (Zhu et al. 2000); one from X. campestris pv. vesicatoria (gi:38564794); and one from X. campestris pv. campestris IS1478a (gi:1927196) (Fig. 3A). The sequence in these elements that is similar to the ecf sequence is outside the 
coding sequence for the transposase but within the element at the $3^{\prime}$ end containing one of the inverted repeats. The second set of similar sequences has significant similarity to ecf bases 49 to 108 and comprises the flanking inverted repeats first found in members of the widespread avrBs 3 family of avirulence genes with virulence functions, and subsequently found flanking or adjacent to other genes in X. campestris pv. vesicatoria (Noel et al. 2003). The most significant similarity was to one repeat flanking avirulence or virulence gene, $p t h N$ (gi:2384735), from the cotton pathogen $X$. campestris pv. malvacearum, followed in significance by a repeat found upstream of $h p a J$ in $X$. campestris pv. vesicatoria (Noel et al. 2003). In each case, the fundamental identity is to the inverted repeat sequence (approximately 95\%), with similarity dropping off completely beyond that region. Like other instances, the repeat is found downstream of the $3^{\prime}$ end of the ecf ORF. There are no other significant similarities in the coding sequence to $a v r B s 3$ genes.

Gene products with limited similarity to the ecf gene product were identified with PSI-BLAST (Fig. 3B). ECF is 15 to $18 \%$ identical and 48 to $52 \%$ similar to uncharacterized proteins in $X$. campestris pv. campestris (gi:21230004 and gi:21111523) and $X$. axonopodis pv. citri (gi:21241314); these three proteins are $71 \%$ identical and $86 \%$ similar. All of the xanthomonad homologues have the colicin Ia C8, C9, and TonB-box domains. In addition, ECF is 11 to $12 \%$ identical and 45 to $47 \%$ similar to a Pseudomonas syringae protein,

Table 2. Bacterial strains, plasmid vectors, and plasmid constructions

\begin{tabular}{|c|c|c|}
\hline Designation & Relevant characteristics $^{\mathbf{a}}$ & Source or reference \\
\hline \multicolumn{3}{|l|}{ Bacterial phytopathogens } \\
\hline \multicolumn{3}{|l|}{ Xanthomonas campestris pv. vesicatoria } \\
\hline $75-3,92-14$ & Tomato race $1, \mathrm{Rif}^{\mathrm{r}}$ & Whalen et al. 1988, 1993 \\
\hline $75-3$ avrRxv:: $\Omega$ & 75-3 with $\Omega$ insertion in $a v r R x v, \operatorname{Rif}^{\mathrm{r}} \mathrm{Sp}^{\mathrm{r}}$ & Whalen et al. 1988 \\
\hline 75-3 ecf::Tn5 avrRxv:: $\Omega, 75-3$ ecf::Tn5 & 75-3 with $\operatorname{Tn} 5$ insertion in ecf, \pm avrRxv $: \Omega \operatorname{Rif}^{\mathrm{r}} \mathrm{Km}^{\mathrm{r}} \pm \mathrm{Sp}^{\mathrm{r}}$ & This study \\
\hline $75-3$ hrp::Tn5 mutants \#38, 5, 139, 57, 132 & 75-3 with $\operatorname{Tn} 5$ insertion in $h r p \mathrm{~A}, h r p \mathrm{~B}, h r p \mathrm{C}, h r p \mathrm{D}, h r p \mathrm{E}$, and $h r p \mathrm{~F}$ & $\begin{array}{l}\text { Bonas et al. } 1991 \\
\text { Ciesiolka et al. } 1999\end{array}$ \\
\hline $89-1$ & Tomato race $2, \mathrm{Rif}^{\mathrm{r}}$ & Whalen et al. 1993 \\
\hline$X$. campestris pv. vesicatoria races & $82-8,85-10,81-23,68-1,69-1 ;$ Rif $^{\mathrm{r}}$ & Minsavage et al. 1990 \\
\hline X. campestris pathovars & phaseoli $85-6$, vignicola $\mathrm{G}-55$, malvacearum G-34, glycines 202 ; Rif $^{\mathrm{T}}$ & Whalen et al. 1988 \\
\hline Agrobacterium tumefaciens $\mathrm{C} 5 \mathrm{C} 81 \pm \mathrm{vir}$ & $\operatorname{Rif}^{\mathrm{r}} \mathrm{Km}^{\mathrm{r}} \pm \mathrm{Tc}^{\mathrm{r}}$ & Van Larebeke et al. 1984 \\
\hline \multicolumn{3}{|l|}{ X. campestris pv. vesicatoria } \\
\hline $85-10 \operatorname{hrpG} *\left(85^{*}\right)$ & 85-10 $h r p G$ mutant with constitutive $h r p$ gene expression; $\operatorname{Rif}^{\mathrm{r}}$ & Wengelnik et al. 1999 \\
\hline $85-10$ hrpG* rec:cya $\left(85^{*}\right)$ & 85-10 hrp $\mathrm{G}^{*}$ rec $A$ gene fused with cya; genomic integration; $\mathrm{Rif}^{\mathrm{T}}$ & Metz et al. in press \\
\hline 85-10 hrp $\mathrm{G}^{*} \Delta h r c \mathrm{~V}\left(85^{*} \Delta h r c \mathrm{~V}\right)$ & 85-10 hrp $\mathrm{G}^{*}$ with $h r c \mathrm{~V}$ mutation; $\operatorname{Rif}^{\mathrm{r}}$ & Rossier et al. 1999 \\
\hline \multicolumn{3}{|l|}{ Escherichia coli strains } \\
\hline DH5 $\alpha$ & F-recA $\phi 80-\mathrm{d} l a c \mathrm{Z} \Delta \mathrm{M} 15$ & BRL \\
\hline XL-1 Blue & 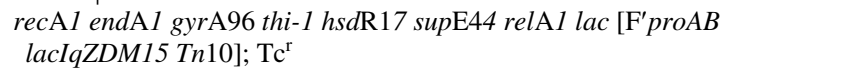 & Stratagene \\
\hline \multirow[t]{2}{*}{ TOP10 } & F-mcrA $\Delta($ mrrhsdRMSmcrBC) $\phi 80 l a c Z \Delta \mathrm{M} 15$ & \\
\hline & 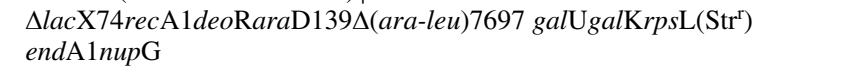 & Invitrogen \\
\hline \multirow[t]{2}{*}{ DB3.1 } & F-gyr462end $\mathrm{A} \Delta(\operatorname{sr} 1 r e c \mathrm{~A}) m c r \mathrm{~B} m r r h s d \mathrm{~S} 20$ & \\
\hline & 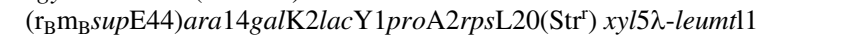 & Invitrogen \\
\hline \multicolumn{3}{|c|}{ 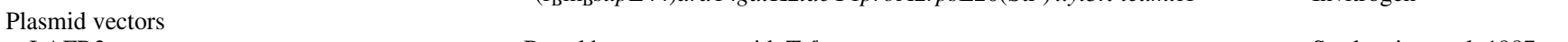 } \\
\hline pLAFR3 & Broad host range cosmid, $\mathrm{Tc}^{\mathrm{r}}$ & Staskawicz et al. 1987 \\
\hline pL6 & pLAFR3 deleted for Plac with $\operatorname{trp}$ terminators flanking the polylinker, $\mathrm{Tc}^{\mathrm{r}}$ & Whalen et al. 1988 \\
\hline pVSP61 & Broad host range vector, $\mathrm{Km}^{\mathrm{r}}$ & DNA Plant Technology \\
\hline \multirow[t]{2}{*}{ pMD1 } & Binary vector plasmid with $35 \mathrm{~S}$ promoter, NOS terminator, $\mathrm{LB}, \mathrm{RB}, \mathrm{Km}^{\mathrm{r}}$ & \\
\hline & & M. Dixon \\
\hline pCRII & TA-cloning vector, $\mathrm{Ap}^{\mathrm{r}}$ & Invitrogen \\
\hline pBluescript KS and SK & Phagemid derived from $\mathrm{pUC19}, \mathrm{Ap}^{\mathrm{r}}$ & Stratagene \\
\hline pRK2013, pRK2073 & Helper plasmids, $\mathrm{Km}^{\mathrm{r}}, \mathrm{Sp}^{\mathrm{r}}$ & Ditta et al. 1980 \\
\hline pENTR/SD/TOPO & Gateway entry vector & Invitrogen \\
\hline \multicolumn{3}{|l|}{ Plasmid constructs } \\
\hline pEC432 & pLAFR 3 clone from $X$. campestris pv. vesicatoria $\mathrm{T} 75-3$ with ecf activity & This study \\
\hline pXV9038 & 3.6-kb Sau3AI subclone from pEC432 in pLAFR3 & This study \\
\hline pEC432::Tn5, pXV9038::Tn5 & $\operatorname{Tn} 5$ insertions eliminating ecf activity & This study \\
\hline pXV9039, pXV9040 & 2.4-kb BamHI-HindIII subclone of pXV9038 in pLAFR3 and pL6 & This study \\
\hline pCQM20 & 2.4-kb subclone of pXV9038 in pL6; no external promotion & This study \\
\hline pJP1 & 2.4-kb ecf subclone in pVSP61 & This study \\
\hline pXV9007 & $a v r R x v$ in pLAFR3 & Whalen et al. 1988 \\
\hline p42 & 2.4-kb insert from pXV9039 in pBluescript & This study \\
\hline p44, p61, p64 & EcoRI-HindIII subclone of $\mathrm{p} 42$ containing base pairs 1 to 1,114 in & ( \\
\hline \multirow[t]{2}{*}{$\mathrm{p} 54, \mathrm{p} 62$} & ExoIII subclone containing base pairs 352 to 2,358 in pBluescript and pL6 & 1ins stucy \\
\hline & & This study \\
\hline \multirow[t]{2}{*}{$\mathrm{p} 55, \mathrm{p} 63$} & ExoIII subclone containing base pairs 536 to 2,358 in pBluescript and pL6 & \\
\hline & & This study \\
\hline pCQM30 & 2.4-kb ecf subclone in pMD1 & This study \\
\hline pMD1-avrBsT & avrBsT in pMD1 & Orth et al. 2000 \\
\hline pMD1-avrRpt2 & avrRpt2 in pMD1 & $\begin{array}{l}\text { Mudgett and Staskawicz } \\
1999\end{array}$ \\
\hline pDD62-Сya & Cya in pVSP61 as destination vector & Metz et al. 2005 \\
\hline pJM50 & ecf $\Delta$ stop in pENTR & This study \\
\hline pJMP51 & ecf:cya fusion in pVSP61 & This study \\
\hline
\end{tabular}

${ }^{\mathrm{a}} \mathrm{Rif}=$ rifampicin, $\mathrm{Sp}=$ spectinomycin, $e c f=$ early chlorosis factor gene, $\mathrm{Km}=$ kanamycin, $\mathrm{Tc}=$ tetracycline, and $\mathrm{Ap}=$ ampicillin. 
HolPsyAE, in pv. syringae B728a (Greenberg and Vinatzer 2003). HolPsyAE is $24 \%$ identical and $55 \%$ similar to HopPmaA in $P$. syringae pv. maculicola, with the majority of the homology in the N-terminus (Greenberg and Vinatzer 2003). The HolPsyAE/HopPmaA N-termini do not cluster with $\mathrm{ECF}$ and the other ECF homologues. Analysis of ECF subcellular localization sequences uncovered a weak chloroplast thylakoid membrane targeting sequence. Moreover, the protein domain similarity search program BLOCKS uncovered some intriguing similarities to the ECF-family in proteins found in chloroplasts, including Photosystem I PsaA and PsaB, Photosystem II PsbH, Cytochrome b6-f complex subunit VI b559, NADH dehydrogenase, and Chlorophyll AB binding protein.

\section{Physiological characterization of $e c f$.}

We assessed the development of two other disease symptoms in $X$. campestris pv. vesicatoria $89-1$, specifically watersoaking and tissue collapse. $X$. campestris pv. vesicatoria 89-1 with $e c f$ appears to have a slight delay in watersoaking but no effect on final tissue collapse. Electrolyte leakage was assessed from leaves of two tomato cultivars after inoculation with strains of 89-1 with and without ecf. A slow rate and low level of electrolyte leakage was observed in both Bonny Best and Hawaii 7998 in response to infiltration with 89-1 carrying the ecf subclone pXV9040 (Fig. 4). The response to ecf was similar to that observed in response to infiltration of Bonny Best and Hawaii 7998 with 89-1, but different from the rapid rate and high level of electrolyte leakage in Hawaii 7998 seen in a
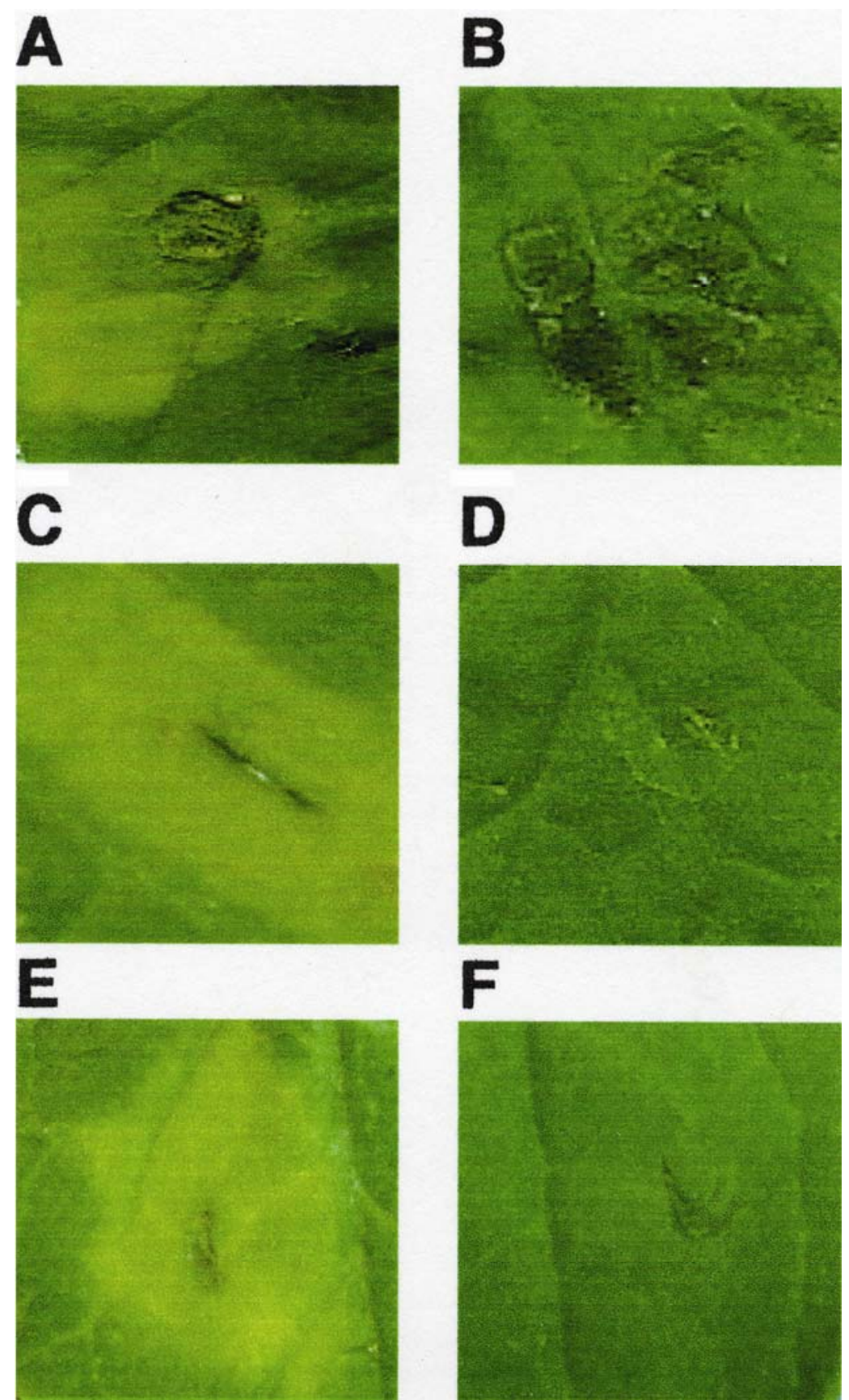

Fig. 1. Response of tomato cultivars to inoculation. Cv. Bonny Best after inoculation with Xanthomonas campestris pv. vesicatoria inoculated at $5 \times 10^{8}$ CFU/ml. X. campestris pv. vesicatoria strain 89-1 carrying pLAFR3 A, with early chlorosis factor gene (ecf) and $\mathbf{B}$, without $e c f$ at 3 days post inoculation (dpi); strain 75-3 C, with intact $h r p$ genes and D, with Tn5 insertion in hrpA at 3 dpi. Cv. VF36 after inoculation with Agrobacterium tumefaciens C5C81 vir $^{+}$carrying $\mathbf{E}, e c f$ in pMD1 (pCQM30) and F, pMD1 alone at 4 dpi. 
hypersensitive response (HR) to 89-1 carrying avrRxv (Whalen et al. 1993). These results indicate that, although ecf appears to slightly delay watersoaking, it does not behave as an avirulence gene in terms of electrolyte leakage. To determine

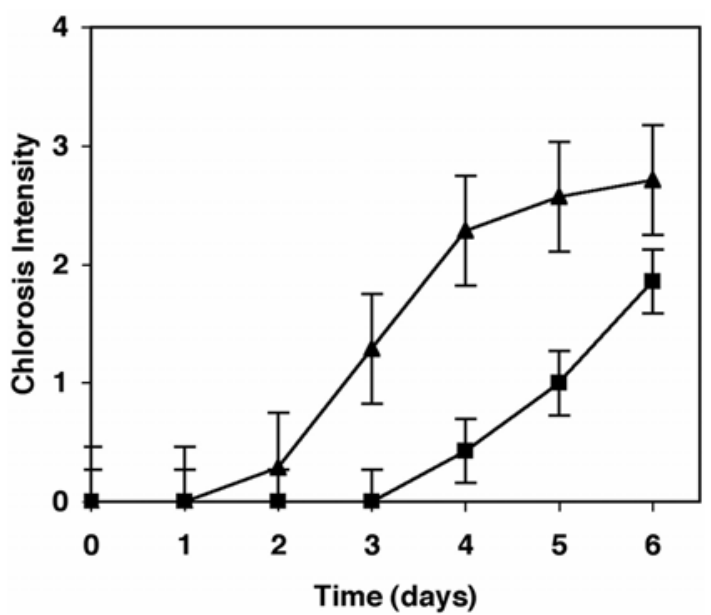

Fig. 2. Time course of intensity of chlorosis in leaves of tomato cv. Bonny Best in response to inoculation with Xanthomonas campestris pv. vesicatoria 89-1 strains inoculated at $5 \times 10^{8} \mathrm{CFU} / \mathrm{ml}$ for up to 6 days post inoculation. The intensity of chlorosis within the inoculated area was visually scored on a scale of 0 to 4 , where $0=$ no chlorosis, $1=$ faint chlorosis, $2=$ light chlorosis, $3=$ medium-bright chlorosis, and $4=$ bright chlorosis. Each point represents the mean \pm SE of seven independent inoculations of pL6 with early chlorosis factor gene in pXV9040 (A) and pL6 alone (ם).
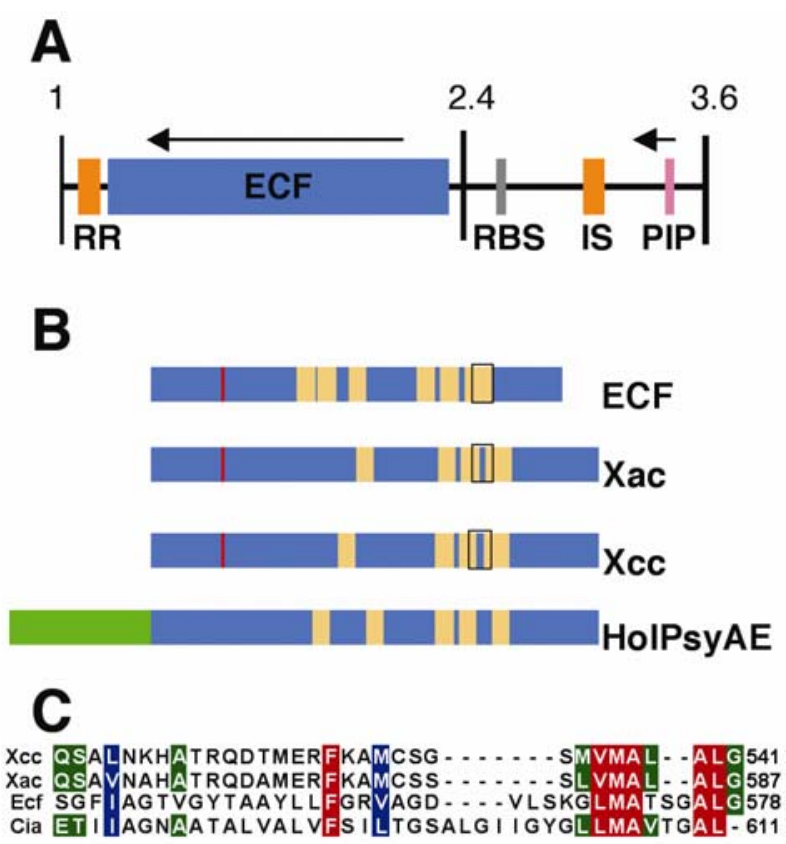

Fig. 3. Bioinformatic analysis of early chlorosis factor gene (ecf). A, Nucleotide sequence of the 3.6-kb ecf-containing clone pXV9038 indicating the ecf open reading frame (blue), repeat elements (avrBs3-family type right repeat [RR] and xanthomonad insertion sequence [IS] type; orange), PIP-box (pink), and ribosome binding site (RBS; gray). B, Alignment of amino acid sequence of ECF and homologues indicating transmembrane domains (yellow), colicin Ia domains including C8/C9 (black box), TonB-box (red), and nonhomologous domain (green). Homologues are uncharacterized proteins from Xanthomonas campestris pv. campestris (Xcc) and X. axonopodis pv. citri (Xac) and HolPsyAE from Pseudomonas syringae pv. syringae. C, Alignment of colicin Ia C8 and C9 domains in ECF homologues indicating identical (red), highly conserved substitutions (blue), and conserved (three of four; green). whether early chlorosis could be due to an impact of ecf on growth in planta, tomato and bean cultivars were infiltrated with bacterial strains and bacterial populations were monitored for 5 days (Fig. 5). The results indicate that, in both tomato and bean, the growth of $X$. campestris pv. vesicatoria 75-3 was the same as 75-3 ecf::Tn5.

Although 75-3 induced chlorosis on susceptible tomato lines, none of the 75-3 hrp mutants tested induced a chlorotic response on tomato (Fig. 1; Table 3). This result suggested the possibility that ecf is normally translocated by the hrp TTSS into host cells. To determine whether ecf induced a chlorotic phenotype independent of Xanthomonas spp., ecf was expressed in planta using an Agrobacterium tumefaciens-mediated transient expression system (Mudgett et al 2000; Tai et al. 1999). The virulent $A$. tumefaciens C5C81 carrying pMD1 (Table 2), containing ecf in pCQM30, induced chlorosis in tomato cvs. Bonny Best and VF-36 (Table 3; Fig. 1). The chlorotic response reached its maximum intensity at $4 \mathrm{dpi}$. No necrosis was evident until 8 dpi. When A. tumefaciens C5C81 that has been cured of the virulence plasmid carried ecf in pCQM30, no host response was evident, demonstrating the requirement for gene transfer to induce the chlorotic phenotype. Nicotiana benthamiana inoculated with pMD1-avrRpt2 (Mudgett and Staskawicz 1999) and pMD1-avrBsT (Orth et al. 2000) responded with necrosis as expected within 2 dpi, indicating that transient expression was functioning normally and HRs were visible (Table 3). It appears that ecf induces chlorosis when directly expressed by the host cell, suggesting that the loss of chlorosis induction in the hrp mutants is a direct effect of preventing translocation.

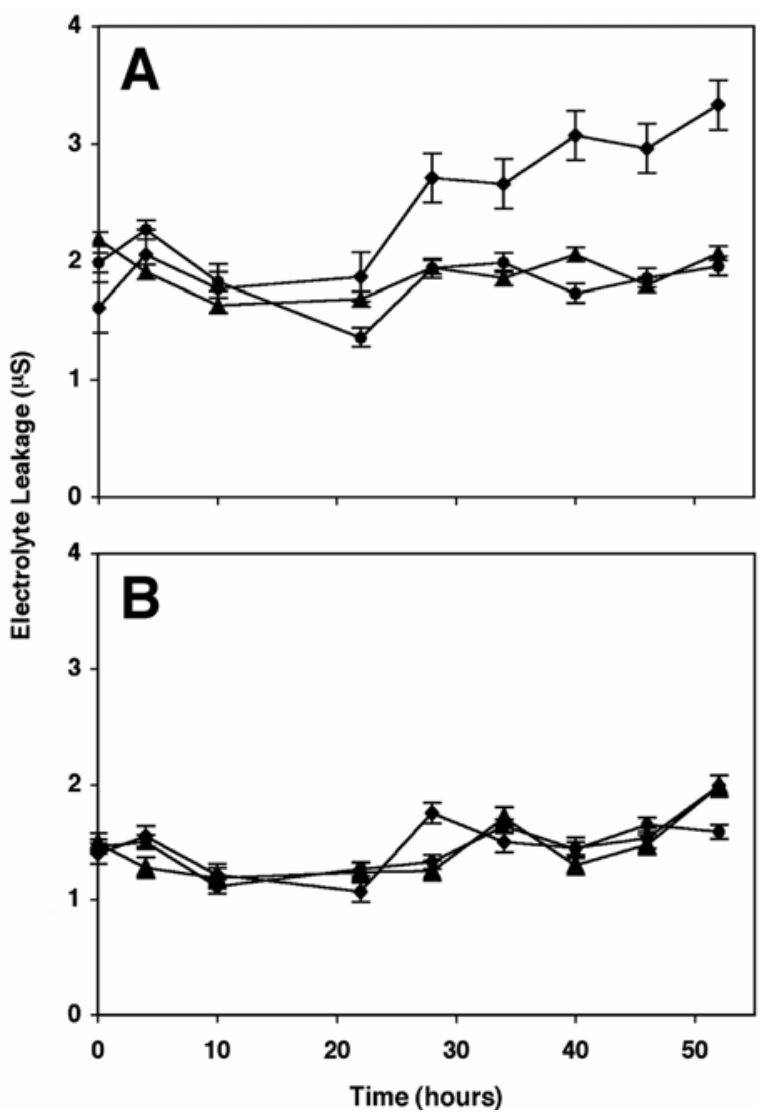

Fig. 4. Electrolyte leakage from leaves of tomato cvs. A, Hawaii 7998 and B, Bonny Best inoculated with transconjugants of Xanthomonas campestris pv. vesicatoria 89-1 at a concentration of $5 \times 10^{8} \mathrm{CFU} / \mathrm{ml}$ carrying

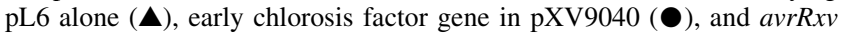
in pXV9007 ( ). Each point represents the mean \pm SE of three replicates. 
To determine whether the ecf gene product is translocated to the host, we examined the cAMP levels in tomato leaves after infection with Xanthomonas strains carrying a translational fusion of the gene for the calmodulin-dependent adenylate cyclase $c y a$ and $e c f$ (Table 2; Fig. 6). At 8 hpi, approximately 30 times more cAMP was produced in $X$. campestris pv. vesicatoria $85^{*}$ (pJMP51) carrying the ecf:cya fusion than $85^{*}$ alone, $85^{*} \Delta \mathrm{hrcV}$ (pJMP51), or $85^{*}$ carrying the nontranslocated recA:cya fusion. These results indicate that the gene product of ecf is translocated to host cells.

To test for a secreted chlorosis-inducing activity, $X$. campestris pv. vesicatoria 89-1 carrying ecf in either pXV9039 or pJP1 (Table 2) were grown in rich (nutrient yeast glycerol; NYG) and hrp-inductive (XVM2) medium (Feneslau and Bonas 1995) and culture filtrates were collected. No chlorosis activity on pepper or tomato was observed in culture filtrates when concentrated up to 30-fold (data not shown). This result

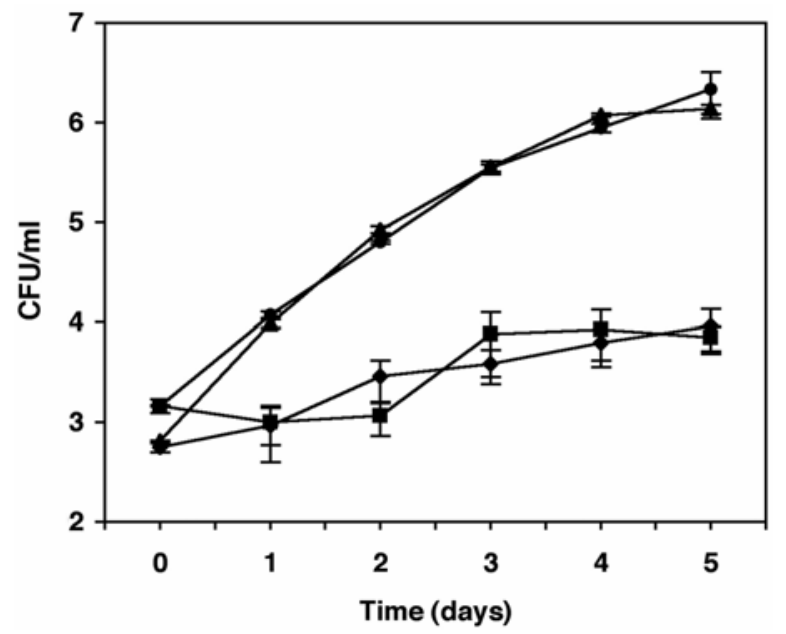

Fig. 5. Time course of bacterial growth in tomato cv. Bonny Best and common bean cv. Bush Blue Lake 274. Leaves were infiltrated with bacterial suspensions of $10^{5} \mathrm{CFU} / \mathrm{ml}$. Bacterial populations in leaves were sampled immediately after infiltration and up to 5 days thereafter. $X$. campestris pv. vesicatoria strain $75-3$ in tomato $(\boldsymbol{A})$ and in bean $(\bullet)$ and strain 75-3 ecf::Tn5 in tomato (O) and in bean (ם). Each point represents the mean $\pm \mathrm{SE}$ of three replicates.

Table 3. Response of tomato and tobacco to inoculation of Agrobacterium tumefaciens $\mathrm{C} 5 \mathrm{C} 81$ with transient assay vector pMD1 carrying specified genes

\begin{tabular}{llc}
\hline & \multicolumn{2}{c}{ Plant response $^{\mathbf{a}}$} \\
\cline { 2 - 3 } Plasmid $^{\mathbf{b}}$ & vir $^{+}$ & vir $^{-}$ \\
\hline & \multicolumn{2}{c}{ VF36/Bonny Best } \\
pMD1-ecf & Chl $^{\text {c }}$ & None \\
pMD1 & None & None \\
& Nicotiana benthamiana \\
pMD1-avrRpt2 & HR & None \\
pMD1-avrBsT & HR & None \\
pMD1 & None & None \\
\hline
\end{tabular}

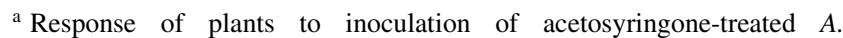
tumefaciens strain at an optical density at $600 \mathrm{~nm}=0.8$; vir $^{+}=$virulent

A. tumefaciens containing the virulence plasmid and $\operatorname{vir}^{-}=$nonvirulent A. tumefaciens lacking virulence plasmid.

$\mathrm{b}$ Transient expression plasmid pMD1 carrying specified bacterial gene; CaMV S35 promoter driving expression of transformed DNA after delivery by A. tumefaciens; $e c f=$ early chlorosis factor gene.

${ }^{\mathrm{c}}$ VF36 routinely responded to $100 \%$ of inoculations with chlorosis; Bonny Best responded, on average, to $94 \%$ of inoculations with chlorosis.

${ }^{\mathrm{d}} N$. benthamiana avrRpt2 and avrBsT reactions included as positive control for hypersensitive response (HR). suggests that the chlorosis-inducing factor is not secreted from $X$. campestris pv. vesicatoria in vitro.

\section{Expression of $e c f$.}

To understand the function of $e c f$, we analyzed the conditions under which it is expressed in X. campestris pv. vesicatoria. Northern blots confirmed a transcript size of approximately $2.1 \mathrm{~kb}$ in $X$. campestris pv. vesicatoria 89-1 strains carrying the plasmid-borne ecf gene that is consistent with the large ORF1 (data not shown). Real-time reverse-transcriptase polymerase chain reaction (RT-PCR) analysis of total RNA from 89-1 carrying ecf in pXV9039 compared with pL6 alone and normalized for the endogenous control 16S rRNA showed that ecf was expressed in both NYG and XVM2 to the same extent (Table 4). Our expression analyses suggest that, although translocation of ECF is dependent on the hrp apparatus, ecf expression is not dependent on nutritional conditions that induce hrp gene expression in $X$. campestris pv. vesicatoria.

\section{DISCUSSION}

Development of control strategies to prevent crop disease or lessen its negative agronomic impact requires an understanding of the factors that contribute to disease symptoms. Chlorosis is one symptom of bacterial spot disease caused by the pathogen of tomato $X$. campestris pv. vesicatoria. We have identified and cloned a gene from $X$. campestris pv. vesicatoria that induces a bright chlorosis on host and nonhost plants. The induction of chlorosis is conditioned by the single locus in $X$. campestris pv. vesicatoria called early chlorosis factor (ecf).

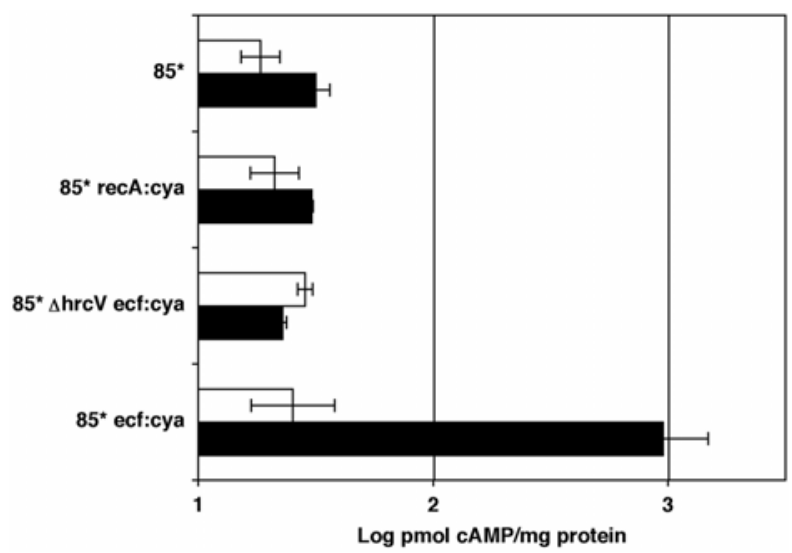

Fig. 6. Activity of calmodulin-dependent cya fusions in tomato $8 \mathrm{~h}$ post infection with Xanthomonas campestris pv. vesicatoria $85-10^{*}$ mutant and transconjugants. Leaves were infiltrated with bacterial suspensions of $5 \times 10^{8}$ cells $/ \mathrm{ml}$ and, immediately thereafter (white) and $8 \mathrm{~h}$ later (black), cAMP levels were determined in two leaf discs $\left(0.5 \mathrm{~cm}^{2}\right.$ each). Each bar represents the mean \pm SE of three replicates.

Table 4. Expression analysis of early chlorosis factor gene $(e c f)^{\mathrm{a}}$

\begin{tabular}{lcc}
\hline & \multicolumn{2}{c}{ Relative expression of $\operatorname{ecf}\left(\mathbf{2}^{\left.-\mathbf{\Delta \Delta C t} \times \mathbf{1 0}^{\mathbf{6}}\right)^{\mathbf{b}}}\right.$} \\
\cline { 2 - 3 } Growth medium & Mean & Range \\
\hline NYG & 1.40 & 0.81 to 2.43 \\
XVM2 & 1.26 & 0.75 to 2.13 \\
\hline
\end{tabular}

${ }^{a}$ By real-time reverse-transcriptase polymerase chain reaction on total RNA from Xanthomonas campestris pv. vesicatoria 89-1 transconjugants grown in nutrient yeast glycerol (NYG) and hrp-inductive (XVM2) medium.

${ }^{\mathrm{b}}$ Expression of ecf in total RNA from 89-1 carrying ecf in pXV9039 compared with pL6 alone. Calculations of relative expression include normalization for endogenous control gene 16S rRNA. 
The chlorosis was evident beginning 2 dpi and increasing in intensity up to $5 \mathrm{dpi}$. On tomato, an additional faint chlorosis activity was apparent in a non-ecf strain beginning at $3 \mathrm{dpi}$ and increasing up to $5 \mathrm{dpi}$, suggesting the possibility of a second chlorosis activity conditioned by at least one other locus in $X$. campestris pv. vesicatoria. Although DNA that hybridizes to ecf is found in chlorosis-inducing strains in $X$. campestris pv. vesicatoria and not in other pathovars of $X$. campestris, when carrying ecf, other pathovars are fully able to induce early chlorosis on their hosts. This suggests that the requirements for function of the protein product of ecf are not specific to $X$. campestris pv. vesicatoria or to its host, tomato.

We examined the effect of ecf on electrolyte leakage and growth of the pathogen in planta. Results from analysis of tomato response to infection indicate that ecf did not significantly affect electrolyte leakage. In both tomato and bean, we have observed that $e c f$ did not affect growth at any time postinfection. The gene ecf delayed the onset of visible watersoaking by approximately 1 day, and it is possible that this is associated with a weak resistance-inducing activity.

Intact $h r p$ genes were necessary for the ecf phenotype and, when directly expressed by plant cells, ecf induced chlorosis. Moreover, analysis of cya activity of ecf:cya in host cells indicated that the ecf-mediated induction of chlorosis may be a direct effect of the translocation of the ecf gene product to the host cell cytoplasm. Although the translocation of ECF is hrp-mediated, the expression of ecf is not dependent on $h r p$-inductive conditions. Taken together, our results suggest that ECF behaves like a virulence effector and contributes to development of symptoms. One class of virulence factors is toxins and, in fact, several pseudomonad toxins induce chlorosis (Alfano and Collmer 1996). However, ECF did not behave like a toxin, as evidenced by a lack of host response to concentrated culture filtrates from ecf-containing $X$. campestris pv. vesicatoria cells grown in rich or $h r p$-inductive medium. To the contrary, our results indicate that $e c f$ encodes a translocated effector.

The coding sequence of ecf has been determined and analyzed for indicators of structure and function. As predicted, the 2,064-nucleotide ORF encodes a protein of molecular weight of approximately $74 \mathrm{kDa}$ and produces a transcript of approximately $2.1 \mathrm{~kb}$. Although a PIP-box is located upstream of ecf, it is unlikely to be part of the ecf promoter, considering the spacing and the fact that, without the PIP-box sequences, ecf functions normally. Moreover, ecf is expressed to the same extent in rich and $h r p$-inductive media. The association of PIPboxes with effector genes does not always mean it is an essential promoter sequence, as evidenced by studies of expression of other genes including $a v r R x v$ (Ciesiolka et al. 1999) and popP (Lavie et al. 2002). Like many effectors, although translocation of ECF is dependent on induction of the hrp system; ecf gene expression is not.

ECF is a hydrophobic protein with an abundance of $\alpha$-helices that potentially may localize to a membrane, as evidenced by six putative TM domains. Remarkably, the tertiary structure of ECF has limited but significant structural similarity to domains of colicin Ia, a pore-forming TM protein present in $E$. coli (Weiner et al. 1997). The colicin Ia similarity with ECF includes the TonB recognition motif (TonB binding box) in the translocation domain, and two of the highly conserved TM sequences, $\mathrm{C} 8$ and $\mathrm{C} 9$, in the channel-forming domain. In general, colicin Ia homologues do not have a high level of sequence similarity except in the $\mathrm{C} 8$ and $\mathrm{C} 9$ domains. Based on the $\mathrm{C} 8$ and $\mathrm{C} 9$ structural similarities, it is possible that, once ECF has been translocated to the host cell cytoplasm, it functions to depolarize chloroplast membranes, resulting in disruption of chloroplast function leading to chlorosis. Mutagenesis studies are essential to provide evidence for this model.
In the nucleotide sequence immediately flanking ecf, similarities were discovered to repeat sequences in other xanthomonads, including $X$. oryzae pv. oryzae, $X$. campestris pv. vesicatoria, and $X$. campestris pv. campestris. Only the region adjacent to and including an inverted repeat sequence was similar, but none of the transposon coding sequence was found. Included in the similarities were the inverted repeats found flanking members of the widespread avrBs 3 family of avirulence and virulence genes. These $a v r B s 3$-family flanking repeat sequences also have been found singly, adjacent to six other genes in $X$. campestris pv. vesicatoria involved in hostpathogen interactions (Noel et al. 2003). These two types of repeat sequences indicate that the region flanking ecf may have been evolutionarily active in genomic rearrangements. The $X$. campestris pv. campestris and $X$. axonopodis pv. citri genomes are rich in transposable elements often found adjacent to strain-specific genes whose features suggest that they possibly were acquired by lateral transfer (da Silva et al. 2002). Recently, seven translocated effectors in $X$. campestris pv. vesicatoria were identified by a genetic screen in $X$. campestris pv. vesicatoria; four of them were novel (Roden et al. 2004).

Phytobacterial gene products with limited similarity to the ecf gene product were found in the genomes of $X$. campestris pv. campestris and $X$. axonopodis pv. vesicatoria, creating a loose family of putative virulence effectors. The three xanthomonad homologues have the colicin Ia C8 and C9 domains and four of six TM domains. In addition, ECF is similar to the C-terminus of a $P$. syringae effector protein, HolPsyAE (Greenberg and Vinatzer 2003). This protein has five of the six TM domains found in ECF and has a region similar to the colicin Ia sequences shared by other ECF family members. HolPsyAE is similar to HopPmaA at their N-terminal domains, where there is no similarity with ECF (Greenberg and Vinatzer 2003). HopPmaA was isolated in a translocation screen, is expressed equally well in $h r p$-inductive and rich medium, is plasmid borne, has chloroplast targeting sequences, and is similar to a prophage protein in pathogenic E. coli (Greenberg and Vinatzer 2003; Guttman et al. 2002). The role these latter proteins play in virulence in unknown. It will be interesting to determine whether the ECF-family factors have similar targets in plants, and whether disruption of chloroplast function is their mode of action.

\section{MATERIALS AND METHODS}

\section{Bacterial strains and plasmids.}

Bacterial strains and plasmids used in this study are listed in Table 1. E. coli strains were grown at $37^{\circ} \mathrm{C}$ in Luria broth (LB) (Miller 1972) or SOC medium (Sambrook et al. 1989). Xanthomonas strains were grown at $30^{\circ} \mathrm{C}$ in $\mathrm{NYG}$ medium (Daniels et al. 1984). A. tumefaciens strains were grown at $28^{\circ} \mathrm{C}$ in LB. Bacto-agar (Difco Laboratories, Detroit) was added to media for plate cultures. The helper plasmid pRK2073 or pRK2013 was used in triparental mating (Figurski and Helinski 1979) to mobilize broad host range vectors from E. coli into Xanthomonas spp. or A. tumefaciens. Antibiotics (Sigma-Aldrich, St. Louis) were used for selection in both liquid and plate cultures at the following concentrations: ampicillin (Ap), 50 or $100 \mu \mathrm{g} / \mathrm{ml}$; rifampicin (Rif), $100 \mu \mathrm{g} / \mathrm{ml}$; tetracycline (Tc), 5 or $10 \mu \mathrm{g} / \mathrm{ml}$; spectinomycin $(\mathrm{Sp}), 50 \mu \mathrm{g} / \mathrm{ml}$; and kanamycin $(\mathrm{Km}), 25$ or $50 \mu \mathrm{g} / \mathrm{ml}$.

\section{Molecular biology techniques.}

Standard molecular biology techniques were used for manipulating plasmids, preparing DNA for sequencing and subcloning, and performing Southern blots. Exonuclease III deletion and subsequent reactions were carried out with the Erase- 
a-Base System (Promega Corp., Madison, WI, U.S.A.). To assess whether the long ORF in the 2.4-kb subclone produced the predicted translation product, in vitro transcription or translation was performed on p42. TNT Coupled Reaction (Promega Corp.) containing 35-S methionine was used according to the manufacturer's instructions and products fractionated on sodium dodecyl sulfate (SDS)-polyacrylamide gels. Genomic DNA was isolated according to Staskawicz and associates (1984) and restriction enzyme digested and transferred to Hybond $\mathrm{N}+$ membrane (Amersham, Piscataway, NJ, U.S.A.) according to the manufacturer's protocols.

For RNA isolations, after lysing Xanthomonas cells from overnight liquid cultures in $0.05 \mathrm{M}$ Tris, $\mathrm{pH} 9.0,0.05 \mathrm{M}$ EDTA, 0.3 M Sodium Acetate, and $0.625 \%$ SDS at $100^{\circ} \mathrm{C}$, RNA in lysate was isolated with RNeasy Mini kits (Qiagen, Valencia, CA, U.S.A.) following the manufacturer's instructions. Total RNA $(5 \mu \mathrm{g})$ was fractionated on a prerun $1 \%$ agarose denaturing gel (19.7 mM MOPS, $\mathrm{pH} 7.0 ; 6.2 \%$ formaldehyde) at $120 \mathrm{~V}$. The RNA was blotted onto a nylon membrane and UV-crosslinked. Southern and Northern blot probes (25 ng) were 32P-dCTP labeled using standard protocols and purified through Sephadex G-50 spin columns. Prehybridization, hybridization, and washes were performed with the ULTRAhyb system (Ambion, Austin, TX, U.S.A.) at $42^{\circ} \mathrm{C}$.

Sequence of ecf and flanking DNA was obtained by sequencing several subclones of the 3.5-kb ecf subclone pXV9038 (Table 1). The $3.5-\mathrm{kb}$ clone containing ecf had sixfold coverage and flanking DNA had onefold coverage. Sequencing reactions were performed on ABI 377 DNA sequencers (PerkinElmer, Norfolk, CT, U.S.A.) using standard protocols and vector sequences for dye-labeled primers. Other internal sequencing primers were designed as necessary using Oligo 5.1 (National Biosciences, Plymouth, MN, U.S.A.). Sequence data was manipulated using Sequencher 3.0 (Gene Codes Corp., Ann Arbor, MI, U.S.A.), MacVector 5.0.1 (Kodak, New Haven, CT, U.S.A.), and Geneworks version 2.5N (Oxford Molecular Group-Accelrys San Diego, CA, U.S.A.). The nucleotide and amino acid sequences were analyzed by programs available on the internet.

\section{Plant growth, inoculations, and physiological analyses of host responses.}

All plants were grown from seed in plastic pots with standard potting mix in a greenhouse. Plant inoculations of Xanthomonas strains at $5 \times 10^{8} \mathrm{CFU} / \mathrm{ml}$ in $\mathrm{H}_{2} \mathrm{O}$ were performed on four different plants and experiments were done in triplicate. Inoculated plants were observed at 24-h intervals from 1 to $15 \mathrm{dpi}$ and disease symptoms (chlorosis, watersoaking, and tissue collapse) were noted and scored for each strain. To assess the effect of gene expression in planta, A. tumefaciens-mediated gene transfer was performed on leaf tissue (Tai et al 1999). A. tumefaciens strains were suspended in $1 \mathrm{ml}$ of induction medium (10 mM 2-[N-Morpholino] ethanesulfonic acid [SigmaAldrich], $10 \mathrm{mM} \mathrm{MgCl}_{2}$, and $200 \mu \mathrm{M}$ acetosyringone [3',5' dimethoxy-4'-hydroxyacetophenone] [Aldrich, Milwaukee, WI]) and incubated at $28^{\circ} \mathrm{C}$ for $2 \mathrm{~h}$. After induction, A. tumefaciens strains were diluted to an optical density at $600 \mathrm{~nm}=0.2,0.4$, 0.6 , and 0.8 , and tomato and tobacco were inoculated with the dilution series and leaves observed as described above for 5 dpi. Three independent experiments were performed each, with several independent transconjugants.

To assess levels of electrolyte leakage, Xanthomonas strains were grown overnight in NYG liquid medium, brought to a cell density of $5 \times 10^{8} \mathrm{CFU} / \mathrm{ml}$ in distilled water, and vacuum infiltrated into leaves of tomato. During a time course postinfiltration, six leaf disks of $0.5 \mathrm{~cm}^{2}$ were taken from each plant using a cork borer and were suspended in $3 \mathrm{ml}$ of distilled $\mathrm{H}_{2} \mathrm{O}$ in $10-\mathrm{ml}$ beakers for $1 \mathrm{~min}$ with vigorous shaking. A conductivity meter was used to read the solution in microOhms every $6 \mathrm{~h}$ for up to $64 \mathrm{~h}$ postinfiltration. Three plants were used for each Xanthomonas strain and the experiment was repeated three times.

To determine the level of bacterial growth in planta, plant leaves were infiltrated with a $10^{5} \mathrm{CFU} / \mathrm{ml}$ in $10 \mathrm{mM} \mathrm{MgCl}_{2}$ bacterial solution by vacuum infiltration, and bacteria were isolated from leaf disks during the course of $5 \mathrm{dpi}$ (Whalen et al. 1988). In all, seven independent growth curves were performed in bean and tomato.

X. campestris pv. vesicatoria 89-1 (p39) and 89-1 (p40) (Table 1) were tested for the presence of a secreted toxin. Overnight cultures were grown in $5 \mathrm{ml}$ of NYG or XVM2 (Wengelnik et al. 1996). Some of the cell suspension was inoculated directly after assessing cell density. Cell suspensions were pelleted twice and supernatants were filtered with a 0.2 -micron filter to remove bacteria. Culture filtrates were concentrated 5- to 30fold with centricon concentrators (Amicon/Millipore, Bedford, MA, U.S.A.) with a molecular weight cutoff of $10 \mathrm{kDa}$. Tomato and pepper plants were inoculated and plant responses were observed for 1 to $4 \mathrm{dpi}$.

\section{Expression analysis.}

Real-time RT-PCR was used to analyze expression of ecf. The ecf and Xanthomonas rRNA expression primers were created using default settings in Primer Express 2.0 (Applied Biosystems, Foster City, CA, U.S.A.). The ecf expression forward primer (5'-GTTGCTCATGCGTGATTGCT-3') and ecf expression reverse primer (5'-TTACGCAGCTTCTCCACGAA-3') amplicon is $111 \mathrm{bp}$ in length. The ecf TaqMan probe consists of an oligonucleotide (5'-CTGTCATCGAACTGCCGAAGCT CCTG-3') covalently attached to the $5^{\prime}$ reporter dye FAM (6carboxyfluorescein) and the $3^{\prime}$ quencher dye TAMRA (6-carboxytetramethylrhodamine) (Applied Biosystems).

To design an endogenous control for real-time RT-PCR of RNA from $X$. campestris pv. vesicatoria $89-1$, Clustal W was used to align xanthomonad 16S rRNA sequences (GenBank identifiers: 4544327, 3153161, 4544328, 4544326, 1657412, 1922934, 1657411, 2266886, 3153162, 4544329, 4544325, and 28170767 ). The $16 \mathrm{~S}$ rRNA forward primer (5'-TGACGGT ACCCAAAGAATAAGCA-3') and $16 \mathrm{~S}$ rRNA reverse primer (5'-ACGCTTGCACCCTTCGTATTA-3') amplicon is $72 \mathrm{bp}$ in length. The 16S rRNA TaqMan probe consists of an oligonucleotide (5'-ACTTCGTGCCAGCAGCCGCG-3') covalently attached to dyes as above.

Two-step real time RT-PCR was used to study ecf expression. The RT reaction was performed in three steps for the two targets independently on $1 \mu \mathrm{g}$ of total RNA following Invitrogen's (Carlsbad, CA, U.S.A.) instructions (2 pmol of each primer, $1 \mathrm{mM}$ dNTPs, $1 \times$ RT buffer, $10 \mathrm{mM}$ DTT, 40 units RNaseout [Invitrogen], and $200 \mathrm{U}$ of RT [Invitrogen]). The Geneamp 5700 sequence detector (Applied Biosystems) was used to perform real-time PCR on $2 \mu \mathrm{l}$ of cDNA. PCR reactions $(50 \mu \mathrm{l})$ contained $100 \mathrm{nmol}$ of each primer/probe, $1 \mathrm{mM}$ dNTPs, $1 \times$ TaqMan Gold buffer, $10 \mathrm{mM} \mathrm{MgCl}_{2}$, and $2.5 \mathrm{U}$ of TaqMan Gold polymerase. After heating samples to $95^{\circ} \mathrm{C}$ for $10 \mathrm{~min}, 40$ cycles were performed, consisting of $95^{\circ} \mathrm{C}$ for $15 \mathrm{~s}$ and $62^{\circ} \mathrm{C}$ for $90 \mathrm{~s}$, followed by $72^{\circ} \mathrm{C}$ for $10 \mathrm{~min}$. rRNA cDNAs were diluted 100-fold compared with ecf samples before realtime PCR. The sizes of the PCR products from the experimental and control reactions were confirmed with agarose gel electrophoresis (data not shown). Calculations for relative expression were performed according to the comparative threshold cycle $(\mathrm{Ct})$ method as described by the real-time PCR system manufacturer (Applied Biosystems). The average $\mathrm{Ct}$ values used in the calculation represent the mean and standard devia- 
tion of three independent RNA samples, with each sample analyzed in triplicate with real-time RT-PCR.

\section{Translocation analysis.}

The Gateway cloning system (Invitrogen) was used to construct the ecf:cya fusion (Table 2). Oligo 5.1 (Molecular Biology Insights Inc., Cascade, CO, U.S.A.) was used to create ecf gateway-specific primers. The ecf-gateway forward primer $\left(5^{\prime}-\right.$ CACCATGCAGATCAAAAC- $3^{\prime}$ ) and ecf-gateway reverse primer 2 (5'-TTCCGACTGAGGCACTGG-3') product is 2,068 bp in length. Full-length ecf $\Delta$ stop codon was PCR amplified using Pfu Turbo polymerase (Stratagene, La Jolla, CA, U.S.A.). PCR reactions contained $100 \mathrm{ng}$ of each primer, $200 \mu \mathrm{M}$ dNTPs, $1 \times$ Pfu Turbo polymerase buffer, $100 \mathrm{ng}$ of p42 template DNA (Table 1), and $2 \mathrm{U}$ of Pfu Turbo polymerase. Reactions were heated to $95^{\circ} \mathrm{C}$ for $3 \mathrm{~min}$, and then 30 amplification cycles were performed at $95^{\circ} \mathrm{C}$ for $30 \mathrm{~s}$ and $55^{\circ} \mathrm{C}$ for $30 \mathrm{~s}$, followed by $72^{\circ} \mathrm{C}$ for $2.5 \mathrm{~min}$.

After confirming the size of the PCR product by agarose gel electrophoresis, amplified DNA was cloned directly into pENTR/SD/TOPO (Invitrogen) to produce the entry vector, pJMP50 (Table 2). The TOPO cloning reaction was performed using $120 \mathrm{ng}$ of fresh PCR product, $1 \mu \mathrm{l}$ of salt solution, and 1 $\mu \mathrm{l}$ of TOPO vector as supplied by the manufacturer and according to their instructions (Invitrogen), and transformed into TOP10 E. coli (Invitrogen). Confirmation of the entry clone pJMP50 was verified by restriction enzyme digestion using $B s r$ GI and by sequencing with M13 forward and M13 reverse primers. pJMP50 DNA was linearized with EcoRV and a 4.7$\mathrm{kb}$ band was gel purified. The LR recombination reaction was used to transfer it into the destination vector, pDD62-Cya (Table 2). The LR reaction (16 $\mu \mathrm{l})$ contained $150 \mathrm{ng}$ of attL1ecf $\Delta$ stop-attL2 and $150 \mathrm{ng}$ of pDD62-Cya, 1× LR Clonase Reaction Buffer, and $4 \mu$ of LR Clonase enzyme mix and was performed and stopped according to manufacturer's instructtions (Invitrogen). Library Efficiency DH5 $\alpha$ competent cells (Invitrogen) were transformed. The sequence of the resulting pJMP51 (ecf:cya fusion) was verified by sequencing. For expression in Xanthomonas spp., pJMP51 and pDD62-cya were conjugated into $X$. campestris pv. vesicatoria $85^{*}$ and $85^{*} \Delta \mathrm{hrcV}$ (Table 2).

To assess the activity of ecf:cya in vitro, Xanthomonas cells were grown overnight and sonicated and, after addition of bovine calmodulin, cAMP levels were measured according to Casper-Lindley and associates (2002) with a cAMP enzyme immunoassay according to the manufacturer's instructions kit (Cayman Chemicals, Ann Arbor, MI, U.S.A.). To determine whether ecf:cya is translocated into tomato cells, Xanthomonas strains at $5 \times 10^{8}$ cells $/ \mathrm{ml}$ in $10 \mathrm{mM} \mathrm{MgCl}_{2}$ were hand infiltrated into tomato leaves as described earlier. For each sample, two leaf discs $\left(0.5 \mathrm{~cm}^{2}\right.$ each $)$ were collected and stored frozen at $-80^{\circ} \mathrm{C}$ until assayed for cAMP as described by Casper-Lindley and associates (2002). Triplicate samples were analyzed and the experiment was repeated three times.

\section{ACKNOWLEDGMENTS}

We gratefully acknowledge M. Huber for performing the in vitro transcription/translation reaction, members of the SFSU spring 1995 Biology 744 class for beginning to sequence and analyze pXV9038, E. Moe for tomato seed production, C. Boucher for help with the sequence analysis, B. Staskawicz for greenhouse facilities, and G. Ponciano for critical reading of the manuscript. All the research and M. C. Whalen were supported by NIH AREA R15 GM59022 and NIH MBRS SCORE grant SO6 GM52588; C. Q. Morales and J. Posada were supported by NIH MBRS RISE R25 GM59298; D. Franklin and J. Posada were supported by NIH MARC T34 GM08574; I. Rivas and M. Bravo were supported by NIH Bridges to the Baccalaureate R25 GM50078; D. Franklin was supported by ASPB 2003 Summer Undergraduate Research Fellowship; and the work was supported by NIH RIMI P20 RR11805.

\section{LITERATURE CITED}

Alfano, J. R., and Collmer, A. 1996. Bacterial pathogens in plants: Life up against the wall. Plant Cell 8:1683-1698.

Bender, C. L., Alarcon-Chaidez, F., and Gross, D. C. 1999. Pseudomonas syringae phytotoxins: Mode of action, regulation, and biosynthesis by peptide and polyketide synthetases. Microbiol. Mol. Biol. Rev. 63:266292.

Bonas, U., Schulte, R., Feneselau, S., Minsavage, G. V., Staskawicz, B. J., and Stall, R. E. 1991. Isolation of a gene cluster from Xanthomonas campestris pv. vesicatoria that determines pathogenicity and the hypersensitive response on pepper and tomato. Mol. Plant-Microbe Interact. 4:81-88.

Brito, B., Aldon, D., Barberis, P., Boucher, C., and Genin, S. 2002. A signal transfer system through three compartments transduces the plant cell contact-dependent signal controlling Ralstonia solanacearum hrp genes. Mol. Plant-Microbe Interact. 15:109-119.

Buell, C. R., and Somerville, S. C. 1995. Expression of defense-related and putative signaling genes during tolerant and susceptible interactions of Arabidopsis with Xanthomonas campestris pv. campestris. Mol. Plant-Microbe Interact. 8:435-443.

Buell, C. R., Joardar, V., Lindeberg, M., Selengut, J., Paulsen, I. T., Gwinn, M. L., Dodson, R. J., Deboy, R. T., Durkin, A. S., Kolonay, J. F., Madupu, R., Daugherty, S., Brinkac, L., Beanan, M. J., Haft, D. H., Nelson, W. C., Davidsen, T., Zafar, N., Zhou, L., Liu, J., Yuan, Q., Khouri, H., Fedorova, N., Tran, B., Russell, D., Berry, K., Utterback, T., Van Aken, S. E., Feldblyum, T. V., D’Ascenzo, M., Deng, W. L., Ramos, A. R., Alfano, J. R., Cartinhour, S., Chatterjee, A. K., Delaney, T. P., Lazarowitz, S. G., Martin, G. B., Schneider, D. J., Tang, X., Bender, C. L., White, O., Fraser, C. M., and Collmer, A. 2003. The complete genome sequence of the Arabidopsis and tomato pathogen Pseudomonas syringae pv. tomato DC3000. Proc. Natl. Acad. Sci. U.S.A. 100:10181-10186.

Buttner, D., and Bonas, U. 2002. Port of entry - the type III secretion translocon. Trends Microbiol. 10:186-192.

Buttner, D., Noel, L., Thieme, F., and Bonas, U. 2003. Genomic approaches in Xanthomonas campestris pv. vesicatoria allow fishing for virulence genes. J. Biotechnol. 106:203-214.

Casper-Lindley, C., Dahlbeck, D., Clark, E. T., and Staskawicz, B. J. 2002 Direct biochemical evidence for type III secretion-dependent translocation of the AvrBs2 effector protein into plant cells. Proc. Natl. Acad. Sci. U.S.A. 99:8336-8341.

Ciesiolka, L. D., Hwin, T., Gearlds, J. D., Minsavage, G. V., Saenz, R., Bravo, M., Handley, V., Conover, S. M., Zhang, H., Caporgno, J., Phengrasamy, N. B., Toms, A. O., Stall, R. E., and Whalen, M. C. 1999. Regulation of expression of avirulence gene avrRxv and identification of a family of host interaction factors by sequence analysis of $a v r B s T$. Mol. Plant-Microbe Interact. 12:35-44

Collmer, A., Lindeberg, M., Petnicki-Ocwieja, T., Schneider, D., and Alfano, J. 2002. Genomic mining type III secretion system effectors in Pseudomonas syringae yields new picks for all TTSS prospectors. Trends Microbiol. 10:462-469.

Cornelis, G. R., and Van Gijsegem, F. 2000. Assembly and function of type III secretory systems. Annu. Rev. Microbiol. 54:735-774.

Daniels, M. J., Barber, C. E., Turner, D. C., Cleary, W. G., and Sawczyc, M. K. 1984. Isolation of mutants of Xanthomonas campestris pv. campestris with altered pathogenicity. J. Gen. Microbiol. 130:2447-2455.

da Silva, A. C., Ferro, J. A., Reinach, F. C., Farah, C. S., Furlan, L. R., Quaggio, R. B., Monteiro-Vitorello, C. B., Van Sluys, M. A., Almeida, N. F., Alves, L. M., do Amaral, A. M., Bertolini, M. C., Camargo, L. E., Camarotte, G., Cannavan, F., Cardozo, J., Chambergo, F., Ciapina, L. P., Cicarelli, R. M., Coutinho, L. L., Cursino-Santos, J. R., El-Dorry, H., Faria, J. B., Ferreira, A. J., Ferreira, R. C., Ferro, M. I., Formighieri, E. F., Franco, M. C., Greggio, C. C., Gruber, A., Katsuyama, A. M. Kishi, L. T., Leite, R. P., Lemos, E. G., Lemos, M. V., Locali, E. C., Machado, M. A., Madeira, A. M., Martinez-Rossi, N. M., Martins, E. C., Meidanis, J., Menck, C. F., Miyaki, C. Y., Moon, D. H., Moreira, L. M., Novo, M. T., Okura, V. K., Oliveira, M. C., Oliveira, V. R., Pereira, H. A., Rossi, A., Sena, J. A., Silva, C., de Souza, R. F., Spinola, L. A., Takita, M. A., Tamura, R. E., Teixeira, E. C., Tezza, R. I., Trindade dos Santos, M., Truffi, D., Tsai, S. M., White, F. F., Setubal, J. C., and Kitajima, J. P. 2002. Comparison of the genomes of two Xanthomonas pathogens with differing host specificities. Nature 417:459-463.

Fenselau, S., and Bonas, U. 1995. Sequence and expression analysis of the hrpB pathogenicity operon of Xanthomonas campestris pv. vesicatoria which encodes eight proteins with similarity to components of the Hrp, 
Ysc, Spa, and Fli secretion systems. Mol. Plant-Microbe Interact. 8:845-854.

Figurski, D. H., and Helinski, D. R. 1979. Replication of an origin-containing derivative of plasmid RK2 dependent on a plasmid function provided in trans. Proc. Natl. Acad. Sci. U.S.A. 76:1648-1652

Fouts, D. E., Abramovitch, R. B., Alfano, J. R., Baldo, A. M., Buell, C. R., Cartinhour, S., Chatterjee, A. K., D’Ascenzo, M., Gwinn, M. L., Lazarowitz, S. G., Lin, N. C., Martin, G. B., Rehm, A. H., Schneider, D. J., van Dijk, K., Tang, X., and Collmer, A. 2002. Genomewide identification of Pseudomonas syringae pv. tomato DC3000 promoters controlled by the HrpL alternative sigma factor. Proc. Natl. Acad. Sci. U.S.A. 99:2275-2280

Greenberg, J. T., and Vinatzer, B. A. 2003. Identifying type III effectors of plant pathogens and analyzing their interaction with plant cells. Curr. Opin. Microbiol. 6:20-28.

Gross, D. C. 1991. Molecular and genetic analysis of toxin production by pathovars of Pseudomonas syringae. Annu. Rev. Phytopathol. 29:247278.

Guttman, D. S., Vinatzer, B. A., Sarkar, S. F., Ranall, M. V., Kettler, G., and Greenberg, J. T. 2002. A Functional Screen for the Type III (Hrp) secretome of the plant pathogen Pseudomonas syringae. Science 295:1722-1726.

He, P., Chintamanani, S., Chen, Z., Zhu, L., Kunkel, B. N., Alfano, J. R. Tang, X., and Zhou, J. M. 2004. Activation of a COI1-dependent pathway in Arabidopsis by Pseudomonas syringae type III effectors and coronatine. Plant J. 37:589-602.

Jin, Q., Thilmony, R., Zwiesler-Vollick, and He, S. Y. 2003. Type III protein secretion in Pseudomonas syringae. Microbes Infect. 5:301-310.

Jones, J. B., Stall, R. E., and Bouzar, H. 1998. Diversity among Xanthomonas pathogenic on pepper and tomato. Annu. Rev. Phytopathol. 36:41-58.

Lavie, M., Shillington, E., Eguiluz, C., Grimsley, N., and Boucher, C. 2002. PopP1, a new member of the YopJ/AvrRxv family of type III effector proteins, acts as a host-specificity factor and modulates aggressiveness of Ralstonia solanacearum. Mol. Plant-Microbe Interact. 15:1058-1068.

Metz, M., Morales, C. Q., Dahlbeck, D., Al Sady, B., Clark, E. T., and Staskawicz, B. J. 2005. The conserved Xanthomonas campestris pv. vesicatoria effector protein $\mathrm{XopX}$ is a virulence factor and suppresses host defense in Nicotiana benthamiana. Plant J. 41:801-814.

Miller, J. H. 1972. Experiments in Molecular Genetics. Cold Spring Harbor Laboratory, Cold Spring Harbor, NY.

Minsavage, G. V., Dahlbeck, D., Whalen, M. C., Kearney, B., Bonas, U., Staskawicz, B. J., and Stall, R. E. 1990. Gene-for-gene relationships specifying disease resistance in Xanthomonas campestris pv. vesicatoria-pepper interactions. Mol. Plant-Microbe Interact. 3:41-47.

Mittal, S., and Davis, K. R. 1995. Role of the phytotoxin coronatine in the infection of Arabidopsis thaliana by Pseudomonas syringae pv. tomato. Mol. Plant-Microbe Interact. 8:165-171.

Mudgett, M. B., and Staskawicz, B. J. 1999. Characterization of the Pseudomonas syringae pv. tomato AvrRpt 2 protein: Demonstration of secretion and processing during bacterial pathogenesis. Mol. Microbiol. 32:927-941.

Mudgett, M. B., Chesnokova, O., Dahlbeck, D., Clark, E. T., Rossier, O., Bonas, U., and Staskawicz, B. J. 2000. Molecular signals required for type III secretion and translocation of the Xanthomonas campestris AvrBs2 protein to pepper plants. Proc. Natl. Acad. Sci. U.S.A. 97:13324-13329.

Noel, L., Thieme, F., Gabler, J., Buttner, D., and Bonas, U. 2003. XopC and XopJ, two novel type III effector proteins from Xanthomonas campestris pv. vesicatoria. J. Bacteriol. 185:7092-7102.

Orth, K., Xu, Z., Mudgett, M. B., Bao, Z. Q., Palmer, L. E., Bliska, J. B., Mangel, W. F., Staskawicz, B., and Dixon, J. E. 2000. Disruption of signaling by Yersinia effector YopJ, a ubiquitin-like protein protease. Science 290:1594-1597.

Petnicki-Ocwieja, T., Schneider, D. J., Tam, V. C., Chancey, S. T., Shan, L., Jamir, Y., Schechter, L. M., Janes, M. D., Buell, C. R., Tang, X., Collmer, A., and Alfano, J. R. 2002. Genomewide identification of proteins secreted by the Hrp type III protein secretion system of Pseudomonas syringae pv. tomato DC3000. Proc. Natl. Acad. Sci. U.S.A. 99:7652-7657.

Ponciano, G., Ishihara, H., Tsuyumu, S., and Leach, J. E. 2003. Bacterial effectors in plant disease and defense: Keys to durable resistance? Plant Dis. 87:1272-1282.

Roden, J. A., Belt, B., Ross, J. B., Tachibana, T., Vargas, J., and Mudgett, M. B. 2004. A genetic screen to isolate type III effectors translocated into pepper cells during Xanthomonas infection. Proc. Natl. Acad. Sci. U.S.A. 101:16624-16629.

Rossier, O., Wengelnik, K., Hahn, K., and Bonas, U. 1999. The Xanthomo- nas Hrp type III system secretes proteins from plant and mammalian bacterial pathogens. Proc. Natl. Acad. Sci. U.S.A. 96:9368-9373

Salanoubat, M., Genin, S., Artiguenave, F., Gouzy, J., Mangenot, S., Arlat, M., Billault, A., Brottier, P., Camus, J.C., Cattolico, L., Chandler, M., Choisne, N., Claudel-Renard, C., Cunnac, S., Demange, N., Gaspin, C., Lavie, M., Moisan, A., Robert, C., Saurin, W., Schiex, T., Siguier, P., Thebault, P., Whalen, M., Wincker, P., Levy, M., Weissenbach, J., and Boucher, C. A. 2002. Genome sequence of the plant pathogen Ralstonia solanacearum. Nature 415:497-502.

Sambrook, J., Fritsch, E. F., and Maniatis, T. M. 1989. Molecular Cloning: A Laboratory Manual. Cold Spring Harbor Laboratory Press, Cold Spring Harbor, NY.

Simpson, A. J., Reinach, F. C., Arruda, P., Abreu, F. A., Acencio, M. Alvarenga, R., Alves, L. M., Araya, J. E., Baia, G. S., Baptista, C. S., Barros, M. H., Bonaccorsi, E. D., Bordin, S., Bove, J. M., Briones, M. R., Bueno, M. R., Camargo, A. A., Camargo, L. E., Carraro, D. M., Carrer, H., Colauto, N. B., Colombo, C., Costa, F. F., Costa, M. C., Costa-Neto, C. M., Coutinho, L. L., Cristofani, M., Dias-Neto, E., Docena, C., ElDorry, H., Facincani, A. P., Ferreira, A. J., Ferreira, V. C., Ferro, J. A., Fraga, J. S., Franca, S. C., Franco, M. C., Frohme, M., Furlan, L. R., Garnier, M., Goldman, G. H., Goldman, M. H., Gomes, S. L., Gruber, A., Ho, P. L., Hoheisel, J. D., Junqueira, M. L., Kemper, E. L., Kitajima, J. P., Krieger, J. E., Kuramae, E. E., Laigret, F., Lambais, M. R., Leite, L. C., Lemos, E. G., Lemos, M. V., Lopes, S. A., Lopes, C. R., Machado, J. A. Machado, M. A., Madeira, A. M., Madeira, H. M., Marino, C. L., Marques, M. V., Martins, E. A., Martins, E. M., Matsukuma, A. Y., Menck, C. F., Miracca, E. C., Miyaki, C. Y., Monteriro-Vitorello, C. B., Moon, D. H., Nagai, M. A., Nascimento, A. L., Netto, L. E., Nhani, A., Jr. Nobrega, F. G., Nunes, L. R., Oliveira, M. A., de Oliveira, M. C., de Oliveira, R. C., Palmieri, D. A., Paris, A., Peixoto, B. R., Pereira, G. A., Pereira, H. A., Jr., Pesquero, J. B., Quaggio, R. B., Roberto, P. G., Rodrigues, V., de, M. Rosa A. J., de Rosa, V. E., Jr., de Sa, R. G., Santelli, R. V., Sawasaki, H. E., da Silva, A. C., da Silva, A. M., da Silva, F. R., da Silva, W. A., Jr., and da Silveira, J. F. 2000. The genome sequence of the plant pathogen Xylella fastidiosa. The Xylella fastidiosa consortium of the organization for nucleotide sequencing and analysis. Nature 406:151-157.

Stall, R. E. 1995. Xanthomonas campestris pv. vesicatoria. Pages 167-184 in: Pathogenesis and Host Specificity in Plant Diseases: Histopathological, Biochemical, Genetic and Molecular Basis, Vol. 1. U. S. Singh, R. P. Singh, and K. Kohmoto, eds. Elsevier Science, Tarrytown, NY, U.S.A.

Stall, R. E., and Hall, C. B. 1984. Chlorosis and ethylene production in pepper leaves infected by Xanthomonas campestris. pv. vesicatoria. Phytopathology 74:373-375.

Staskawicz, B. J., Dahlbeck, D., and Keen, N. T. 1984. Cloned avirulence gene of Pseudomonas syringae pv. glycinea determines race-specific incompatibility on Glycine max. Proc. Natl. Acad. Sci. U.S.A. 81:60246028.

Staskawicz, B. J., Dahlbeck, D., Keen, N. T., and Napoli, C. 1987. Molecular characterization of cloned avirulence genes from race 0 and race 1 of Pseudomonas syringae pv. glycinea. J. Bacteriol. 169:5789-5794.

Szurek, B., Rossier, O., Hause, G., and Bonas, U. 2002. Type III-dependent translocation of the Xanthomonas AvrBs3 protein into the plant cell. Mol. Microbiol. 46:13-23.

Tai, T. H., Dahlbeck, D., Clark, E. T., Gajiwala, P., Pasion, R., Whalen, M. C., Stall, R. E., and Staskawicz, B. J. 1999. Expression of the Bs 2 pepper gene confers resistance to bacterial spot disease in tomato. Proc. Natl. Acad. Sci. U.S.A. 96:14153-14158.

Van Larebeke, N., Engler, G., Holsters, M., Van den Elsacker, S., Zaenen, I., Schilperoort, R. A., and Schell, J. 1984. Large plasmid in Agrobacterium tumefaciens essential for crown gall inducing ability. Nature 252:169-170

Weiner, M., Freymann, D., Ghosh, P., and Stroud, R. M. 1997. Crystal structure of colicin Ia. Nature 385:461-464.

Wengelnik, K., Marie, C., Russel, M., and Bonas, U. 1996. Expression and localization of HrpA1, a protein of Xanthomonas campestris pv. vesicatoria essential for pathogenicity and induction of the hypersensitive reaction. J. Bacteriol. 178:1061-1069.

Whalen, M. C., Stall, R. E., and Staskawicz, B. J. 1988. Characterization of a gene from a tomato pathogen determining hypersensitive resistance in non-host species and genetic analysis of this resistance in bean. Proc. Natl. Acad. Sci. U.S.A. 85:6743-6747.

Whalen, M. C., Wang, J. F., Carland, F. M., Heiskell, M. E., Dahlbeck, D., Minsavage, G. V., Jones, J. B., Scott, J. W., Stall, R. E., and Staskawicz, B. J. 1993. Avirulence gene avrRxv from Xanthomonas campestris pv. vesicatoria specifies resistance on tomato line Hawaii 7998. Mol. PlantMicrobe Interact. 6:616-627.

Zhu, W., Magbanua, M. M., and White, F. F. 2000. Identification of two novel hrp-associated genes in the hrp gene cluster of Xanthomonas oryzae pv. oryzae. J. Bacteriol. 182:1844-1853. 